\title{
Professional education of teachers in physical training and health: the experience of Denmark
}

\author{
Roliak A.O. ${ }^{\mathrm{ABCDE}}$ \\ Foreign Languages Department, State Agrarian and Engineering University in Podillia, Ukraine
}

Authors' Contribution: A - Study design; B - Data collection; C - Statistical analysis; D - Manuscript Preparation; E - Funds Collection.

\begin{tabular}{|c|c|}
\hline \multicolumn{2}{|l|}{ Abstract } \\
\hline Purpose: & $\begin{array}{l}\text { Today physical training becomes an integral part of the European education system as it brings } \\
\text { knowledge and insight centered on principles and concepts of the } 21^{\text {st }} \text {-century learning skills. The article } \\
\text { offers an analysis of the structural model, content and goals of the basic physical education projects in } \\
\text { the professional teacher training system of Denmark. As this country has gained a positive experience in } \\
\text { creating its own strategies for reforming of all the important teacher education components, based on } \\
\text { the widespread use of modern motion-focused technologies in the learning process. }\end{array}$ \\
\hline Material: & $\begin{array}{l}\text { Data for this study were collected from multiple sources of Ukrainian, European and Danish educational } \\
\text { environments at various time points from } 1990 \text { to } 2019 \text {. Three cultural generations of } 50 \text { scientific articles } \\
\text { that researched the topics of physical training teachers' education have been chosen. }\end{array}$ \\
\hline Results: & $\begin{array}{l}\text { Our research reveals that the Danish strategy of "healthy nation" with the "sports-for-all" approach calls } \\
\text { for the new generation teachers, pedagogically competent in their physical training subjects and able to } \\
\text { promote healthy life thinking. }\end{array}$ \\
\hline Conclusions: & $\begin{array}{l}\text { Three major projects: "Learning in motion", "Put the school into motion", "Learning and Talent in Sport" } \\
\text { brought considerable impact into physical training teacher education in the Danish environment, } \\
\text { implementing innovative ideas of the close connection between learning abilities and physical activities. } \\
\text { The research findings may be used in reforming physical training teacher education in Ukraine, especially } \\
\text { its transformation from traditional to innovative type by means of the overall implementation of the } \\
\text { modern strategies, assimilating movement and physical exercises into the teaching process. }\end{array}$ \\
\hline $\mathbf{K}$ & anish dimension, healthy life thinking. \\
\hline
\end{tabular}

\section{Introduction}

At the present stage of social development, the majority of countries in the world pay great attention to the health conditions of their nations, and physical culture and sport are regarded as vehicles for health promotion [1]. Physical education provides an excellent opportunity for all to learn and practice sport skills that will enhance lifelong fitness and good health. Moreover, mastery of the basic sport skills will help young people to perform and understand the value of physical activities better in their future life, at work or during leisure time [2]. However, in European dimension, physical education is not limited to training in sport skills and has more than just an entertaining aspect [3]. Involvement in physical activities brings knowledge and insight centered on principles and concepts of the 21 st-century learning skills. They may be regarded as: social inclusion (awareness linked to personal interaction and teamwork), competitiveness (rules of the game and fair play), continuous personal development and tactics of individual growth [4].

With the increase of the physical and mental health problems caused by sedentary lifestyles and obesity, all European countries recognize the importance of physical education at all levels [5]. A significant role in this process is given to teachers of physical training. They are considered to be carriers of the health values of a developed society and without their active participation, progressive changes are impossible. Teachers play a key

(c) Roliak A.O., 2020

doi:10.15561/26649837.2020.0307 role in transmitting the policy aims of physical and sports education into effective practice at school [6]. Educators themselves, embodying the concept of a "healthy nation", are able to target their students to mastering basic sport skills (including healthy lifestyle) [7]. These skills will help young citizens to be prepared better for employment difficulties in the international labor market adapting to work and live in an epoch of fast change, physical and psychological pressure [8].

The social and educational functions of sport are recognized by the 2009 Lisbon Treaty. Article 165 is regarded by the European Union as a legal basis for a new competence on physical training and sport. It calls pedagogic communities for action to develop the European dimension in sports education [9]. So teachers should be prepared for the intensive increase in promoting the development of physical education and sport activity in the school learning process. Thus, physical training, sport and healthy lifestyle must become an integral part of the professional education of a modern teacher.

However, it should be emphasized that from the point of view of physical training teachers professional education in Ukraine there are quite serious contradictions. On the one hand, on a country-wide basis, there is a clear tendency to reform the entire system of teacher education. On the other hand, limited access to information sources, lack of coordination, internal resistance to innovations at local levels prevent educational institutions from meeting their strategic goals to train high-quality specialists with the $21^{\text {st }}$-century skills and competencies. Therefore 
Ukrainian specialists find it difficult to compete in the international labor market [10]. In order to overcome such contradictions, it is necessary to make a substantial upgrade of the entire education system in the country including the professional education of physical training teachers. We consider that a comparative study will contribute to a better understanding of educational situation with the professional teacher training system in advanced European countries and will help to justify new approaches to training of future PT teachers in Ukraine.

The subject matter of our study is the professional teacher training system structure in Denmark. We consider this focus to be essential since Denmark has gained positive experience in creating its own strategic plans for reforming all the teacher education structural components. Moreover these transformations were based on the widespread political will to develop and encourage sports activities as a determinant of social well-being and health [11].

In the context of our research, comparative analysis of teacher education systems around the world is valuable. The general trends in the development of humanistic pedagogic education in democratic states were highlighted by Ukrainian comparativists: Mukan [12], Lytovchenko and Ogiienko [13]. The principles of the organization of teacher training in higher education institutions of European countries were revealed by Tezikova and Pukhovska [14], Leshchenko et al. [15]. The analysis of scientific sources made it possible to state that different aspects of physical training in the system of Ukrainian education are investigated in the works of such scholars as Ivashchenko and Moskalenko [16]. Different physical education practices in Ukraine during its transition into European environment were substantiated by Krasilshchikov et al. [10].

Our comparative study of modern European environment demonstrated that the number of studies on the subject of physical training and health education has increased significantly. The results show that the subject matter of pedagogical practices with training of students to some sports techniques and development of sport biology in context of the population health and physical activity are investigated by American and European scholars. Thus Warner (USA) [17], Łubkowska et al. (Poland) [18] research the issues relating to the theory and practice of physical activity, sports and health. The role of sport in the context of education and as a means of healthy lifestyles in European dimension were discussed in the works of Naul (Germany) [19, 20], Matthiessen et al. [9].

Although comparative research in physical training and sport is growing, investigation into the subject of PT teachers training in European countries are still, with a few exceptions, rare [21]. Nevertheless the content analysis of the received data from pedagogical literature and dissertations has demonstrated that the problem of professional education of a physical training teacher in Danish environment, was not the issue of a systematic study. So that is why, we think it requires the special inquiry.
More specifically the following goals will be considered:

1) to examine the structure of physical training teacher professional education in Denmark;

2) to define and characterize the basic physical education projects through their influence on the PT teachers programs content, and;

3) to identify the area of PT teacher professional competence in Danish educational dimension.

\section{Materials and methods.}

Data sources.

Data for this study were collected using the systematic, synergetic, culturological, axiological approaches to the comparative analysis of pedagogical phenomena. Basic information was gathered from multiple sources of Ukrainian, European and Danish educational environments at various time points from 1990 till 2019. We choose more than three social and cultural generations of 50 scientific articles that researched the topic of physical education. The following sources were analyzed: Eurydice reports and monitoring on physical education and sport in Europe; documents of European Physical Education Association (EUPEA); Denmark physical activity factsheets; Bachelors and Masters programs of Danish-style physical education and sport in VIA University College, Gerlev Physical Education and Sports Academy, University of Southern Denmark; B.Ed. programs for primary and lower secondary school teachers approved by Danish Ministry of Education and Science; European pedagogical periodicals, in particular: European Journal of Education, European Educational Research Journal, Scandinavian Journal of Educational Research, Pædagogik, DPU Quarterly: Teacher Education, Årbog for Dansk Skolehistorie; materials and theses of scientific conferences conducted by national and international scientific organizations on problems of teachers professional training.

\section{Research Design}

The systematic search of the European documents was conducted in three stages.

The first stage was "material collection". This stage included compellation of existing research data (in the Internet base) according to the object of the conducted study. The second stage was "selection and inclusion". The information was selected for its inclusion into the current study within the publication context, dates limits, publication languages - English and Danish. The third stage "synthesis completion" was conducted through both writing up and live-discussions of the research results and critical feedback from Nordic and Ukrainian scholars.

\section{Qualitative analysis}

The data collection took place via Internet resources, in a short-term research project within the funds of the Royal Library of Denmark in Copenhagen and during the author's personal participation in European ECER Conferences, arranged in Denmark and Nordic countries.

A case study has been used to formulate structural characteristics of PT teacher training in its functional 
connectivity with the Danish educational system [22]. Using a case study approach that includes qualitative methods and is based on analytical induction and generalization, a "contextualized comparison" has been carried out to identify characteristic features of teacher education in institutions of higher learning of Denmark and to explore the process in chronological order [23].

\section{Results}

Features of PT teacher education in Denmark

For a detailed study of the physical training and health teachers professional education model in Denmark, let us dwell on the general characteristics of this country's initiatives in this sphere. Our research reveals that in the European educational setting, Denmark is considered to be the country that takes constant care of different aspects of the population's health-related behaviors, focusing on developing a sports culture in schools and different educational institutions [24]. The new Political Agreement on Sports (Politisk stemmeaftale om idræt), adopted in May 2014, launched the Danish strategy of "healthy nation" using a so-called "sports-for-all" approach [25]. In the result two main action plans have been started in Denmark to further enhance physical activity: 1) the updated Folkeskole Act of 2014, focusing on improving physical activity in schools [26] and 2) the campaign "Learning in motion" (Læring i bevægelse) [27]. The latter aimed at encouraging future teachers to choose physical training and health as their core subject and to expand the incorporation of PT technologies into all levels of overall Danish education system.

This means that Denmark calls for new generation teachers, pedagogically competent in their PT subjects. Danish teachers should be able to organize and practice in sports and physical activities, to promote a healthy way of life, to increase the motivation of young people for physical exercise, involving them in various sports that develop healthy life thinking [27]. To do this, future PT teachers should receive appropriate initial education and continuous professional development [28].

Analysis of the curriculum documents and results of surveys show that Denmark goes its own way and has its own strategy in the direction of physical training and health teachers professional education [29].

We distinguish two peculiar features in Danish teacher education: 1) Denmark is the only Nordic country that has a dual system of teacher education; 2) the Bachelor degree in education qualifies to be a teacher in two or three subjects (not in one as in Ukraine and the majority of European countries).

So, we continue our analysis, taking into account these above-mentioned characteristics. It is necessary here to clarify exactly what is meant by "duality" in Danish dimension. In this paper, duality is defined as "the dual perspective" for future teachers to receive tertiary education both in the professional sector, represented by university colleges and academic sector, represented by universities $[30,31]$. Teachers are needed in Danish schools of two levels [32]: 1) Folkeskoles (public secondary schools) and 2) Hejskoles (public and private upper secondary schools). So appropriately there are two basic types of teacher education programs: medium-term and long-term programs [29].

Universities and colleges in the structure of Danish physical training and health teacher education

Our research has tended to focus on the fact that approximately two-thirds of qualified physical training and health teachers work in Danish primary and lower secondary schools [31]. They have to complete a medium-term (mellemfristet videregående uddannelse - MVU) Bachelor of Education program. From the first of January 2008, the medium-term training programs (MVU) for Danish PT teachers of secondary schools are equivalent to 240 European Credit Transfer System (ECTS) [31]. Four years of specialized pedagogical training are implemented in 8 university colleges, which are unique Danish non-profit institutions under public administration. VIA University College, University College of South Denmark, UCC University College, Gerlev Physical Education and Sports Academy are famous for their special, unique educational programs for physical training and health teachers.

It is important to note that the final third of physical training and health teachers in Denmark are mainly involved in teaching for upper secondary schools (both public and private), vocational colleges, adult education, and social institutions [31]. Moreover, there are famous all over the world "Athletic", "Gymnastics and Sports" folk high schools, founded by gymnast and educator Niels Ebbesen Mortensen Bukh [33]. These schools have special focus on physical education, where about half of the course is dedicated to sports, while the other half is of more general education [19]. Teachers in such institutions must accomplish research-based long-term Master of Education programs (langsigtet videregående uddannelse - LVU) in universities [20].

The flexibility of Danish pedagogical education is easy to demonstrate by the fact that any student, having completed a medium-term program, can become a student of a long-term one through the system of credit units enrollment. After the first three years of professional education at the university, a Bachelor's degree is awarded. Bachelor's degree in a PT teacher training program may be both the final point or the starting part in the educational trajectory change. Pedagogic education may continue to the Master's degree, as well as the Doctor of Philosophy (Filosofisk doktor - PhD) or the Doctor of Pedagogical Sciences (læge i pædagogiske Videnskaber) [34].

In the result of the postmodern reforms, the Danish government reduces the number of universities from 12 to 8 , five of which combine several pedagogic faculties, including physical training, sports, and health. Universities in Denmark have a high degree of autonomy and self-governance [35]. The first place in the structure of PT education belongs to the University of Copenhagen (Københavns Universitet), the oldest university in the country with almost twenty-six thousand students. Aarhus 
University (Aarhus Universitet), established in 1928 as a private institution, after the recent transformation, is operating under the control of the Danish Ministry of Education; and is almost twice as small as the University of Copenhagen. The youngest university in which PT teachers are trained is located in Odense (Odense Universitet/SDU). It trains 5,500 students, one-third of whom studies sport culture and humanities [36].

From 2011 the University of Southern Denmark takes an active part in the research-based projects "The Child Database" (Børnedatabasen) [37]. It has become compulsory for Danish schools to report on schoolchildren progress in physical activity, making it possible to evaluate the effect of increased schools PT on pupils' body composition. These data are collected and assessed by the researchers of the University of Southern Denmark. Thus the implementation and the effects of a nationwide school-based health initiative on PE and PA are objectively measured. These results influence both teacher education content and research. Our analysis demonstrates that this practice is unique for the Danish environment corresponding national routine surveillance of PA does not exist in any European country [38].

A major reform of teacher education in Denmark has as its guiding principles: deregulation, internationalization and a strong connection between teacher training and the needs of the Danish public school system [37]. In recent years Denmark suffers from an insufficient number of teaching staff for secondary schools. Thus in 2015, the number of admissions to Danish pedagogical higher education institutions was 2,943 students, compared with 3,710 applicants in 2011 [31]. So the Danish Ministry of Education submitted for consideration a special credit transfer program for mobile training of teachers for schools at all levels. In the result, an alternative pathway to obtaining teacher qualification in physical training is the merit-teacher program, which addresses students with prior vocational work experience or a higher education degree. This allows students to transfer credits from relevant (vocational) experience to the teacher education. Consequently, the program is comparatively short and lasts only for two and a half years, comprising 150 ECTS. Therefore more teachers in a shorter period of time may join pedagogic teams satisfying labor market needs as well as the interests of every particular Danish school [36]. In such a way, in the result of current transformations, short-term (kortvarig videregående uddannelse - KVU) programs recently became available in Danish PT teacher education [35].

The current study found that the characteristic feature of physical education in Denmark schools is that it is sport and health-focused (the Folkeskole subject is called "Physical Training and Health") [39]. Danish professional PT teachers hold the general view that schools, Folkeskoles, first and foremost are much more than just a place of a child education. They have a much wider social function, which is to prepare future members of a democratic society for adulthood and to make young people aware of responsibility for their own lives, showing them how to be socially involved in a local community [40]. So the traditional task of a physical training teacher, consisting in the formation of sports skills and physical abilities of students, has gone away into the past [41]. Danish PT teachers today see their mission in the development of personal and social $21^{\text {st }}$-century skills such as active citizenship and personal independence, self-esteem, self-efficacy, leadership, ability to work in a team, self-confidence, collaboration, competition, healthy way of life including mental well-being, etc [42].

\section{Discussion}

In this section of our analysis we want to discuss the influence of the basic Danish physical training and sport focused projects on PT teachers education content.

Our research demonstrates that the situation with physical education in Denmark was not always as positive as it is at present moment. Danish schools experienced gradual reduction from seven to four lessons a week in 1937, from four to three in 1960, from three to two in 1980 [21]. Only over last ten years, when this country chooses sports-for-all model, the situation has changed [43].

Denmark becomes a pioneer in the development of the global initiative "Learning in motion". We must stress that Danish physical education is characterized by sports-oriented secondary schools, offering sports as either a specific program or as an available option with extra physical education lessons [43]. As we have already mentioned, in the Danish democratic environment, physical education and health instructors are also teachers of two other subjects. So very often they aim for flexibility concerning physical activities, general motoric development, and different learning approaches to support education in a broader holistic sense [42]. Background for this position lies in the ideas of the research program LET'S (Learning and Talent in Sport), belonging to Physical education and innovative teaching, founded by the University of Southern Denmark (SDU), Department of Sports science and Clinical Biomechanics. LET'S scholars investigate practical experiences by implementing innovative ideas and strategies in physical education and sport, making action transformation in sports practice and learning [39]. From the point of view of Danish LET'S program researchers, there is a close connection between learning abilities and physical movement or sports activities. The Danish Evaluation institute together with LET'S has conducted an assessment, showing that physical activity has a positive impact on pupils' learning environment. In particular, the findings show a positive influence on the students' motivation to learn, as well as on their communicational skills and their social environment [44].

Taking into account these conclusions, the project "Put the school into motion" (Sæt skolen i bevægelse) initiated the new integrated cross-subject educational curriculum for future PT teachers in colleges and universities [43]. This curriculum constructed around modules that will help future Danish teachers of primary and lower- 
secondary schools to assimilate movement and physical exercises into their teaching, in order to strengthen the pupils' learning, health, resilience, and well-being [45].

These three modules are the following:

1) the first module, "integration", a course, in which the students teachers are educated in the various ways of integrating movement into their teaching of core subjects (very often the supported subjects could be Mathematics, Physics, English or Social Science);

2) the second module, "study in motion", gives a wide variety of exercises, methods, tools and strategies which the future teachers can incorporate into their teaching in order to encourage movement and creativity;

3) the third module, "practical physical training", these are classes of competitions, games, outdoor activities and ideas of healthy way of life $[39,46]$.

As PT teachers educational curriculum in Danish colleges and universities consists of four main blocks: 1) educational subjects in the form of general educational theory, psychology, and educational science; 2) citizenship/ livsoplysning; 3) two or three core subjects (physical training among them); 4) teaching practice. Consequently the abovementioned modules are incorporated into almost all the subject blocks of the curriculum [36].

The purpose of these interdisciplinary modules is, on one hand, to support future teachers to combine theoretical knowledge, practical ideas, and skills with the latest research on the connection between learning abilities and physical movement or activities [47]. Our study has demonstrated that Danish scholars in pedagogy and psychology press the point that pupil's learning abilities are contingent upon both concentrations, psychological, physiological, social and cognitive aspects [30]. Such a learning approach aims at making the teaching situation more benign for learning abilities to thrive by stimulating some of these aspects through movement and physical exercises [48]. On the other hand, the modules (especially the third one) provide particular ideas on how to make physical training lessons more efficient, applying different new movement activities such as motoric fundamentals, traditional games, brain-break exercises, body-balance control or minor aerobic challenges [49].

Another important aspect that we want to discuss in this study is what competences a teacher of physical training and health should have to be efficient in Danish classroom environment. In European pedagogical research the term "competence" is an evaluative [50]. It denotes the ability of a teacher to use knowledge and skills in practical professional activities [51]. In total such education program content encourages five levels of PT teacher competence development:

- first - knowledge about how to implement and combine learning abilities with physical activity; - second - ability to design teaching in various subjects where physical activities and movement are included and support the learning objectives;

- third - knowledge about using physical activities within the subjects, as in-between 'brain breaks' or co-curricular subject-connections;
- fourth - ideas for physical activities and motoric fundamentals;

- fifth - ability to initiate innovation processes and develop activities according to the student's age, level, and learning content [46, 52].

This competence area represents the strategic goal for future sport-focused teacher education in Denmark. The suggested competence levels may be regarded as that way in which all the transformations in the education of physical training and health teachers for Danish schools should be directed [42]. Our analysis of the advanced features of the sport-related pedagogic education system in Denmark makes it possible to formulate our own effective strategy bringing transformational changes into physical training as an important component of Ukrainian teacher education.

\section{Conclusions}

Thus, the conducted study allows us to make the following conclusions:

- the peculiar feature of physical training teacher professional education model in Denmark is its duality or the twofold perspective for the future PT teachers to receive tertiary education both in the professional sector, represented by university colleges and also academic sector, represented by universities;

- three major projects: "Learning in motion", "Put the school into motion", and research program LET'S (Learning and Talent in Sport) brought considerable impact into PT teacher education in the Danish environment, implementing innovative ideas of the close connection between learning abilities and physical movement or sports activities;

- five main professional competency levels may be regarded as a strategic goal for future sport-focused PT teacher education in Denmark.

The analysis of Danish experience may be used in reforming physical training and sports education in Ukraine, especially its transformation from traditional to innovative type by means of the overall implementation of the modern strategies, assimilating movement and physical exercises into the teaching process.

\section{Suggestions for further research}

We assume that the results drawn from this particular study may provide a clearer picture of general prospects for the use of Danish experience in the Ukrainian educational environment. They may comprise the following:

- transformations in teacher education structure duality in structure and flexibility of Danish PT teacher education programs should be good practice for Ukraine. These include the variety for student choice of subjects and elements within the program, not least the limitations on the preference of key school subjects. It also implies the possibilities for credit transfer from different types of higher education including university study program for example in special semiautonomous professional institutions, so-called Centers for Higher Education (university colleges, CVUs) to the teacher education 
program, and vice versa;

- co-existence of long-term (broad) programs; medium-term and short-term (narrow) programs in PT teachers professional training. "Broad educational programs will generally appeal to students whose motives for education are part of their desire to develop themselves as persons. They can start a study program with the aim of finding out in the process who they are and want to be, and then later adopt a more specific plan for education and career. Narrow educational programs, on the other hand, will appeal to students who take a stronger interest in professional skills and work in personal development [34, p.11]";

- Danish training concept of a school teacher not of one, but of two or even three core subjects (at the request of a student-teacher) can become a perspective one on the basic level of Ukrainian lifelong pedagogic education system. At the same time, Danish experience shows that the main subjects of specialization should not be related (since such experience in training of teachers of Ukrainian and foreign languages or mathematics and physics already exists in Ukraine). Wider specialization profile of future teachers will give an opportunity to the Ukrainian higher pedagogical educational institutions to be more flexible to respond to the needs of the regions and the country as a whole.

This research is not exhaustive. The importance of the discussed problems determines the necessity of their continuous study. We see the prospects for further comparative investigation in the design of the content and methods for the formation of professional competencies for the PT teachers of various educational programs both in Nordic and Ukrainian dimensions.

\section{Conflict of interests}

The author states that there is no conflict of interests.

\section{References}

1. Hills S, Walker MB, Barry A. Sport as a vehicle for health promotion: A shared value example of social programming. Sport Management Review, 2019; 22(1): 126-141. https://doi.org/10.1016/j.smr.2018.10.001

2. Edwards MB, Rowe K. Managing sport for health: An introduction to the special issue. Management Review journal, 2019; 22: 1-4. https://doi.org/10.1016/j.smr.2018.12.006

3. European Commission. White paper on sport. Brussels: Directorate General for Education and Culture; 2007.

4. World Health Organization. Global action plan on physical activity 2018-2030: more active people for a healthier world. Geneva: WHO office; 2018.

5. European Commission, EACEA, Eurydice. Physical Education and Sport at School in Europe. Brussels: Eurydice and Policy Support; 2013.

6. UNESCO. Quality Physical Education. Guidelines for Policy Makers. Paris: UNESCO; 2015.

7. Edginton CR, Chin M-K, Geadelmann P, Ahrabi-Fard I. Global Forum for Physical Education Pedagogy 2010 (GoFPEP 2010): Health and physical education pedagogy in the 21 st century - A statement of consensus. International Journal of Physical Education, 2011; 48(2): 33-41.

8. Shane P. Physical education - what's in a name? A Praxis model for holistic learning in physical education. Healthy Lifestyles Journal, 2007; 54(1): 5 - 10.

9. Matthiessen J, Andersen L, Barbieri H, Borodulin K, Knudsen V, Kørup K, et al. The Nordic Monitoring of Diet, Physical Activity, Smoking, Alcohol and Overweight: 2011-2014. EJNFS, 2017;7:128-30. https://doi.org/10.9734/EJNFS/2017/35072.

10.Krasilshchikov O, Krutsevich T, Smolius G, Davydenko O. Physical Education Practices in Ukraine: Transition From the Past to the Future. In: Ming-Kai Chin, Edginton CR, editors. Physical Education and Health: Global Perspectives and Best Practice. Sagamore Publishing LLC; 2014. P. 503-515.

11. World Health Organization. World Physical activity strategy for the WHO European Region 2016-2025. Vilnus: Regional office for Europe; 2015.

12.Mukan N, Myskiv I, Kravets S. The Characteristics of the Systems of Continuing Pedagogical Education in Great Britain, Canada and the USA. Comparative Professional
Pedagogy, 2016; 2 (6): 20-25.

13.Ogienko O, Lytovchenko I. Technology of self-directed learning in the context of informatization of educational process. Edukacja-Technika-Informatyka, 2011; 2 (2): 93-98.

14.Pukhovska L, Tezikova S, Bazeliuk N, Muzichenko Yu. Constructing the training process model for the European dimension implementation into the in-service teacher training in Ukraine. Paper presented at the European Conference on Educational Research (ECER): Education and Cultural Change; Helsinki; 2010 Aug. 23-27.

15.Leshchenko M, Yatsishin A. Category of "Open Education" in the Work of Native and Foreign Scientists. Information Technologies and Learning Tools, 2014; 1 (39): 1-16.

16. Moskalenko O. Program framework of health and fitness work in preschool institutions in Ukraine. Theory and Methods of Physical Education and Sports, 2011; 3: 59-63.

17.Warner S. Sport as medicine: How F3 is building healthier men and communities. Sport Management Review, 2019; 22(1): p. 38-52. https://doi.org/10.1016/j.smr.2018.06.006

18.Łubkowska W, Paczyńska-Jędrycka M, Eider J. The Significance of Swimming and Corrective Exercises in Water in Treatment of Postural Deficitis and Scoliosis. Central European Journal of Sport Sciences and Medicine, 2014; 6 (2): 93-101.

19.Naul R. The European dimension of Danish gymnastics. In: Hansen J. \& Grinderslev N. editors. The sport and society, body and culture. Sports history Arbog. Odense: University publisher; 1998. P. 35-49. (In Danish) https://doi.org/10.7146/ffi.v14i0.31766

20.Naul R. Physical education and public health in Europe. Paper presented at Conference: Up-to-date information on the educational area of Man and Health. Prage: Charles University; 2015.

21.Annerstedt C. Physical Education in Scandinavia with a Focus on Sweden: A Comparative Perspective. Physical Education and Sport Pedagogy, 2008; 13(4): 303-318. https://doi.org/10.1080/17408980802353347

22.Hodge K, Sharp L. Case studies. In: Smith B, Sparkes AC, editors. Routledge handbook of qualitative research in sport and exercise. New York, NY: Routledge; 2016. P. 62-74.

23. Stake RE. Qualitative case studies. In: Denzin NK, Lincoln YS, editors. The SAGE handbook of qualitative research, 3rd 
ed. Thousand Oaks, CA: Sage; 2005. P. 443-466.

24.Rønholt H. Physical education in Denmark. In: Pühse U, Gerber M. editors. International comparison of physical education: Concepts, problems, prospects. Aachen: Meyer \& Meyer; 2005. P. 206 - 227.

25.Blossing U, Imsen G, Moos L, editors. The Nordic Education Model. Dordrecht: Springer Netherlands; 2014. https://doi.org/10.1007/978-94-007-7125-3.

26.Enactment of the law on primary school [Internet]. Copenhagen: Danish Ministry of Education; 2014 [cited 2015 July 15]. (In Danish). Available from: (https://www. retsinformation.dk/Forms/R0710.aspx?id=163970\&exp=1

27.Larsen LR, Troelsen J, Kirkegaard KL, Christensen B, Riiskjær S, Krølner R, et al. The Danish Report Card on Physical Activity for Children and Youth. Odense: Reach; 2017.

28.Viscione I, Invernizzi P, Raiola G. Physical education in secondary higher education. Journal of Human Sport and Exercise. 2019; 14(4proc): p.706-712. https://doi.org/10.14198/jhse.2019.14.Proc4.31

29. Ogienko O, Rolyak A. Comparative characteristics of the main tendencies of teachers education in Ukraine and Scandinavian countries. Paper presented at The European Conference on Educational Research (ECER): From Teaching to Learning?; Gothenburg; 2008.

30. Ogienko O, Rolyak A. Humanization as the basic tendency of teacher education: European context. Paper presented at the European Conference on Educational Research (ECER): Education and Cultural Change; Helsinki; 2010.

31.The KOF Education System Factbook: Denmark. 1st ed. Zurich: KOF Swiss Economic Institute; 2017.

32. Ministry of Education. Announcement of the law on primary school. LBK nr. 1510, §15. København; 2017. (In Danish)

33.Leonard FE. Physical Education in Denmark (Classic Reprint). Wheelers: Fb\&c Limited; 2018.

34.Staugaard HJ, Rasmussen P. Current challenges to teacher education in Denmark. Paper presented on the 11-th Nordic Teacher Education Conference, Proceedings; Hjørring; 2010. P.11-21.

35.European Commission. Structural Indicators for Monitoring Education and Training Systems in Europe - 2019: Overview of major reforms since 2015. Eurydice Report. Luxembourg: Publications Office of the European Union; 2019.

36.UNESCO. World Data on Education. Denmark. $7^{\text {th }}$ ed. UNESCO: IBE; 2012.

37.Pedersen NH, Koch S, Larsen KT, Kristensen PL, Troelsen J, Møller NC, et al. Protocol for evaluating the impact of a national school policy on physical activity levels in Danish children and adolescents: the PHASAR study - a natural experiment. BMC Public Health, 2018;18(1): p.12-45. https://doi.org/10.1186/s12889-018-6144-8

38.Kirk D, McDonald D, O'Sullivan M, editors. The handbook on physical education. London: SAGE; 2006.

39.Bugge A, Möller S, Tarp J, Lima R, Hillman C, Gejl A, Klakk H, Wedderkopp N. Influence of a School-based Physical Activity Intervention on Scholastic Performance - The
Champs Study - DK: 772 May 31315 PM - 330 PM. Medicine \& Science in Sports \& Exercise, 2017; 49(5S): 198-199. https://doi.org/10.1249/01.mss.0000517382.71784.52

40.Pühse U. International Comparison of Physical Education: Concepts, Problems, Prospects. Oxford: Meyer \& Meyer Sport Ltd; 2005.

41.Green K. Understanding Physical Education. London: SAGE; 2008.

42.Bugge A, Tarp J, Østergaard L, Domazet SL, Andersen LB, Froberg K. LCoMotion - Learning, Cognition and Motion; a multicomponentclusterrandomized school-basedintervention aimed at increasing learning and cognition - rationale, design and methods. BMC Public Health, 2014, 14: 967. https://doi.org/10.1186/1471-2458-14-967

43.Rexen C, Ersbøll AK, Møller NC, Klakk H, Wedderkopp $\mathrm{N}$, Andersen L. Effects of extra school-based physical education on overall physical fitness development the CHAMPS study DK. Scandinavian Journal of Medicine \& Science in Sports, 2015; 25(5): p.706-715. https://doi.org/10.1111/sms.12293

44.Fedewa AL, Ahn S. The effects of physical activity and physical fitness on children's achievement and cognitive outcomes: a meta-analysis. Research Quarterly for Exercise and Sport, 2011; 82 (3): p. 521-535. https://doi.org/10.1080/02701367.2011.10599785.

45.Mitchel S, Oslin J, Griffin L. Teaching Sport Concepts and Skills: A Tactical Games Approach for Ages 7 to 18. 3-d ed. NY: Human Kinetics; 2013.

46.Capel S, Whitehead M. Learning to Teach Physical Education in the Secondary School: A companion to school experience. 4-th ed. Routledge; 2015.

47. Whitehead M. Definition of Physical Literacy and Clarification of Related Issues. ICSSPE. Journal of Sport Science and Physical Education: Bulletin, 2013; 65: 29-34.

48.Crum B.J. Conventional Thought and Practice in Physical Education: Problems of Teaching and Implications for Change. QUEST , 1993; 45: 339- 356. https://doi.org/10.1080/00336297.1993.10484092

49.Griffin LL, Butler J, editors. Teaching games for understanding: Theory, research, and practice. Champaign IL: Human Kinetics; 2005.

50.Ogienko O, Rolyak A. Competent Approach in Teachers Professional Training in Context of Integration to the European Educational Environment. Paper presented at International European Conference on Educational Research (ECER): Theory and Evidence in European Educational Research; Vienna; 2009.

51.Laursen P.F. Educating the Authentic Teacher. In: Lindgren $\mathrm{U}$, editor. A Nordic Perspective on Teacher Education in a time of Societal Change. Umea: Umea University Publ.; 2007. p. 65-76.

52.Weinert, F. E. Concept of competence: A conceptual clarification. In: Rychen D, Salganik L, editors. Defining and Selecting Key Competencies. Seattle, WA: Hogrefe \& Huber; 2001. p. 45-65. 


\section{Information about the author:}

Roliak A.A.; PhD in Pedagogy, Associate Professor; https://orcid.org/0000-0002-0283-6157; rolyakangel@gmail.com; Foreign Languages Department, State Agrarian and Engineering University in Podillia; Mikhailovsky descent 6/1, 32301, KamyanetsPodilsky, Ukraine.

Cite this article as:

Roliak AO. Professional education of teachers in physical training and health: the experience of Denmark.

Pedagogy of physical culture and sports, 2020;24(3):143-150.

https://doi.org/10.15561/26649837.2020.0307

This is an Open Access article distributed under the terms of the Creative Commons Attribution License, which permits unrestricted use, distribution, and reproduction in any medium, provided the original work is properly cited (http://creativecommons.org/licenses/by/4.0/deed.en).

Received: 02.10.2019

Accepted: 10.11.2019; Published: 05.01.2020 